\title{
The Strategic Implications of Black EMpowerment Policy in South Africa: A CASE Study of Boundary Choice AND Client Preferences in a SMall Services Firm ${ }^{1}$
}

\author{
Willem H Boshoff \\ Department of Economics, Stellenbosch University
}

Accepted: February 2012

This paper studies the relationship between a firm's boundary choices within its value chain and the BEE
pressures it faces from its clients. The paper shows that BEE policy alters the value chain preferences of a
firm's clients. These changes in client preferences motivate the firm to altering its boundaries. More
important, boundary changes due to BEE are implemented in a way that ensures that the firm retains crucial
architectural knowledge, which preserves its competitive advantage. Firms therefore do not respond
passively to BEE-induced changes in client preferences, but aim to meet BEE aims within their broader
strategic environment.

Key words: boundaries, vertical integration, black empowerment, demand-side

JEL: D22, L22, M14

\section{1}

\section{Introduction}

Management research recognizes the role of government policy in shaping strategic business decisions in various developing and developed countries (Hall \& Soskice, 2001). Studying the impact of government policy on firm strategy is particularly important in the South African context: since 1994, firms in this country have had to deal with extensive institutional change aimed at redressing historical imbalances created under the Apartheid regime (Chabane, Goldstein \& Roberts, 2006). Specifically, the post-Apartheid government has introduced a far-reaching black economic empowerment (BEE) policy aimed at increasing black participation in the economy (Black, 2002). Academic literature has studied the impact of BEE policy on mergers and acquisitions as well as investment returns (Jackson, Alessandri \& Black, 2005; Strydom, Christison \& Matias, 2009; Wolmarans \& Sartorius, 2009). By contrast, research on the impact of BEE on strategic decisions and value chain structures is still scarce. Yet such research is of practical importance to managers who seek to balance BEE requirements with a range of other strategic goals within their existing value chain structures. Research on the impact of BEE on firm strategy may also offer insights to policymakers, given the social pressures to focus on 'broad-based' BEE policy, which aims to raise black participation in value chains as well as black ownership or employment (Visser, 2005; Hayes, 2006; Bolton, 2008).

This paper contributes to the literature on the strategic implications of BEE by studying the relationship between a firm's boundary choices within its value chain and the BEE pressures it faces from its clients. To this end, the paper has three research objectives. First, to show that BEE policy alters the value chain preferences of a firm's clients. Second, to show that such changes in client preferences lead the firm to altering its boundaries, i.e. to adjust the extent of its activities within the value chain. Third, and most important, to show that boundary changes due to BEE may be implemented in such a way as to ensure that the firm retains crucial architectural knowledge that preserves its competitive advantage. In sum, the overall aim of the paper is to show that firms do not respond passively to BEEinduced changes in client preferences, but aim to shape their strategic environment, at the same time meeting BEE aims. 
The paper contains an in-depth case study of a small South African services firm. As discussed below, single-case studies are useful when developing theory on under-researched areas. The case study is based on a setting in which BEE policy is a dominant feature in the strategic landscape owing to the large number of public-sector clients in the meter-reading industry. Despite this idiosyncratic setting, the case provides a starting point for research on the mechanisms whereby BEE has changed value chain structures in South Africa. The case suggests that BEE affects client preferences, confirming the portrayal of BEE policy as demand-based (Jackson et al., 2005) and further shows that the implementation of BEE policy varies significantly among clients. The demand-altering effect and heterogeneous nature of BEE policy are important issues for the manager, who must understand the likely effects of BEE policy on the firm and formulate strategic responses that balance heterogeneous client preferences with firm competences and profit considerations. The case then explores flexible boundaries as one strategic response to this environment.

The paper commences with a short literature review and description of the research questions and then proceeds to the methodology and data sections. These are followed by the case analysis and results, and then the final conclusions.

\section{2}

\section{Literature review and research questions}

After 1994, the post-Apartheid government in South Africa embarked upon an ambitious social transformation programme in an attempt to address the inequalities generated under the Apartheid system. An important component of this transformation effort has been the roll-out of a far-reaching black economic empowerment (BEE) policy. This policy has three focus areas, all aimed at assisting black South Africans to enter and succeed in the mainstream economy: first, 'direct' empowerment (a reference to the increase in ownership and management by black persons); second, 'human resource development' (referring to affirmative action and skills development among black employees); and, third, 'indirect' empowerment (referring to black business development and preferential procurement) (Republic of South Africa, 2006).

An important feature of BEE, therefore, is that black ownership and management is not considered sufficient (or even necessary) to earn high BEE scores: suppliers also earn BEE points based on their own procurement and skills development decisions (Bolton, 2008). The aim is to alter demand along value chains in a cascading fashion, ensuring that the policy consequences transform the larger economy. It is important, from the strategic perspective, exactly what value chain transformation entails. Structural change in value chains suggests changes in the boundaries of individual firms, which leads to Research Question 1 of this paper: If BEE is aimed at altering demand along value chains, does it lead to changes in boundary decisions by firms?

BEE policy alters demand via an incentivebased policy based on a scorecard system. Under the scorecard system, firms that engage in meaningful BEE practices earn BEE scores that enhance their ability to win government contracts (Department of Trade and Industry, 2007). The private sector has adopted similar practices in evaluating contracts (Republic of South Africa, 2006). However, the scorecard system evolved slowly over time and the lack of uniform guidelines resulted in heterogeneous practices across sectors - see, for example, Fauconnier and Mathur-Helm (2008) for a mining-sector perspective and Horn (2007) for an automotive industry perspective. Consequently, policymakers introduced a balanced scorecard awarding specific points for specific aspects of a supplier's empowerment profile. Table 1 presents the balanced scorecard. As pointed out above, the scorecard seeks to promote direct empowerment (e.g. awarding points to firms that are owned or managed by black South Africans), human resource development (e.g. awarding points to firms that promote the development of skills under black workers) and indirect empowerment (e.g. awarding points to firms that source from black subcontractors).

For illustrative purposes, consider the 20 per cent awarded to indirect empowerment efforts in the form of 'preferential procurement'. An allocation of 20 per cent implies that, when a firm buys 100 per cent of its inputs from 
'preferential' (i.e. black) suppliers, it will be awarded 20 points. Conversely, sourcing all inputs from suppliers with 100 per cent white ownership would attract 0 points.

Table 1

BEE scorecard

\begin{tabular}{|l|c|}
\hline \multicolumn{1}{|c|}{ Component } & Weight \\
\hline Direct empowerment & \\
Equity ownership & $20 \%$ \\
Management & $10 \%$ \\
\hline Human resource development & \\
Affirmative action & $10 \%$ \\
Skills development & $20 \%$ \\
\hline Indirect empowerment & \\
Preferential procurement & $20 \%$ \\
Enterprise development & $10 \%$ \\
\hline Residual & \\
Sector specific component & $10 \%$ \\
\hline
\end{tabular}

Source: Republic of South Africa (2006)

For illustrative purposes, consider the 20 per cent awarded to indirect empowerment efforts in the form of 'preferential procurement'. An allocation of 20 per cent implies that, when a firm buys 100 per cent of its inputs from 'preferential' (i.e. black) suppliers, it will be awarded 20 points. Conversely, sourcing all inputs from suppliers with 100 per cent white ownership would attract 0 points.

Despite the guidelines provided by the balanced BEE scorecard, actual BEE requirements vary significantly. This variety is at least partly a path-dependent result of pre-scorecard sectorspecific initiatives to accelerate transformation, which have had to be incorporated into formal scorecards (Arya, Bassi \& Phiyega, 2008). More important, however, is that the variety is a function of implementation: certain features of BEE, such as community development, may be considered more important in certain contexts, depending, inter alia, on local political conditions (see the summary of the institutional features of BEE policy by Arya \& Bassi (2009)). Implemented weights may, therefore, differ from the official weights. If demand leads to boundary change, as suggested by Research Question 1, the heterogeneity in BEE preferences leads to Research Question 2: If heterogeneity in BEE policy leads to heterogeneity in client preferences faced by a particular firm, does it lead the firm to adopt heterogeneous boundary structures?
Even though firms will respond to BEEbased client preferences, firms also act strategically. In particular, they may engage in unproductive strategies to acquire BEE status. The South African government and industry organizations therefore increasingly emphasise the need to eliminate so-called 'fronting' (Martin \& Root, 2010), which implies a recognition on the part of policymakers that firms accommodate BEE policy as part of a complex strategic environment. This gives rise to Research Question 3: If firms are not merely passive responders to policy, how do they use changes in boundary structure to maintain their competitive advantage in light of BEE requirements?

The three research 'questions' developed above are better described as research 'themes', as the paper follows a case study approach to develop new theoretical propositions rather than to test particular hypotheses. The following section explains the rationale for employing case study research.

\section{3}

\section{Research methodology}

The paper employs case study as research method to explain the three research questions. The case study is an appropriate research method for developing theory, as it facilitates an exploratory and explanatory research mode 
essential to theory-building; case study research supports exploratory analysis by allowing multiple forms of evidence, while it is also better suited than quantitative analysis to explaining "why" and "how" questions (Yin, 2003).

Single-case studies are often employed when the case at hand offers a 'critical' test of a particular theory or when the case is 'extreme', i.e. when a particular phenomenon is rare and every case involving the phenomenon is worth documenting. Another motivation, and the one underlying this paper, is that the case is 'revelatory'. A case is revelatory when it affords the researcher the opportunity of studying phenomena not previously investigated, usually owing to a lack of data (Yin, 2003:42). Black empowerment is a common strategic challenge facing many South African firms, but research into its deep strategic implications is limited, as it requires unrestricted access to corporate data sources and, furthermore, continuous engagement with managers and other agents within the firm. A case that affords such access can assist the researcher in uncovering new organizational phenomena relating to black empowerment that are difficult to identify using conventional research techniques such as surveys (Eisenhardt \& Graebner, 2007).

The usefulness of the single-case study is demonstrable by its position in contemporary management research, especially when the aim is the development of new theory (examples of recent single-case studies in front-ranking strategic management journals include Jacobides (2005), Jacobides and Billinger (2006) and Helfat and Eisenhardt (2004)). Yet some critics have argued that the generalization and validation of research findings from a singlecase study are challenging. The following paragraphs respond to these criticisms.

Critics of case study research often question the external validity of case study findings, arguing that they do not readily generalize to a larger population of firms. This critique relies on an implicit comparison of the case study method with survey research. However, surveys are aimed at 'statistical generalization', i.e. at selecting a representative sample of firms and inferring specific features of the population from this sample. Case studies, on the other hand, are aimed at 'analytical generalization'
(Yin, 2003). Like a single experiment, a single-case study is aimed at building or generalizing a theory from empirical data (Eisenhardt, 1989). In an overview of the epistemology of single-case studies, Buchanan quotes Mitchell (1983) to explain the aims of a single-case study (Buchanan, 1999:S75):

"In case studies statistical inference is not invoked at all. Instead, the inferential process turns exclusively on the theoretically necessary linkages among the features in the case study. The validity of the extrapolation depends not on the typicality or representativeness of the case but upon the cogency of the theoretical reasoning."

A research approach focusing on the development rather than on the generality of a theory is particularly important in under-researched areas (such as the strategic implications of BEE). Edmondson and McManus (2007) advocate the use of case studies (including single-case studies) to develop 'suggestive' theory. In fact, even if a single-case study aims merely to identify a set of 'stylized facts', it is already an important contribution to understanding under-researched phenomena (Flyvbjerg, 2006).

Some critics may insist that generalisation is required for scientific research. But generalisation is not essential to scientific research and the skill to generalise is but one of many practical skills that scientists have to possess if they are to carry out scientific research (Kuhn, 1970). Scientific research requires, first and foremost, an openness to scrutiny and critical feedback established via the peer-review process (Popper, 1963). On this basis, the rich account in a case study arguably allows for a much more thorough challenge to assumptions and biased views than many quantitative techniques. Furthermore, single-case studies are no less scientific than multiple-case studies. Flyvbjerg (2006:235) notes that multiple-case studies do not necessarily outperform single-case studies, as "even single-case studies 'are multiple in most research efforts because ideas and evidence may be linked in many different ways"'. In fact, Runde and De Rond (2010) show that causal explanations derived from single-case studies can be assessed according to objective standards.

The single-case study is therefore an 
appropriate scientific method for the purposes of studying the strategic implications of BEE policy. The following section explains the various data sources employed for the case study.

\section{4}

\section{Data}

The firm under investigation is MRS, ${ }^{1}$ a small South African firm providing meter-reading services to municipalities and private-sector clients. Meter-reading refers to the periodic collection (reading) of water and electricity consumption data. The consumption data is registered on metering devices located at homes, industries and businesses, and meterreaders visit each site in person to collect the consumption data. In developed countries meterreading no longer involves visits in person and data is transmitted electronically, but this has not yet been implemented extensively in South
Africa (Clark, 2000). South African municipalities and private property managers therefore outsource meter-reading to private contractors.

For the purposes of this paper, the MRS case is particularly useful for demonstrating the effect of BEE on the demand side of the market, as MRS and the meter-reading industry do not experience significant supply-side related changes over the same period (Siggelkow, 2007).

The author was actively involved with MRS as a part-time consultant from 1999. This involvement provided the author with the spatial and temporal understanding necessary to study structural change at MRS. The research was conducted from December 2007 to June 2009 as part of a larger research project. The analysis relies on multiple sources of evidence, including documentary evidence, interviews and direct observation. Interviews took the form of extensive semi-structured discussions with the owner and IT manager of MRS and with MRS's joint venture partners.

Table 2

Sources of documentary evidence

\begin{tabular}{|c|c|c|c|}
\hline & $\begin{array}{l}\text { Research question } 1 \text { and } 2 \\
\text { (developing theory) }\end{array}$ & $\begin{array}{c}\text { Research question } 1 \text { and } 2 \\
\text { (exploring rival explanations) }\end{array}$ & Research question 3 \\
\hline $\begin{array}{l}\text { Documentary } \\
\text { evidence from } \\
\text { tender bids }\end{array}$ & $\begin{array}{l}\text { Tender invitation documents } \\
\text { outlining empowerment and } \\
\text { service requirements and tender } \\
\text { reply documents outlining the } \\
\text { firm's proposal for the } \\
\text { particular tender }\end{array}$ & Tender reply documents & $\begin{array}{l}\text { Attendance register for tender bid } \\
\text { meetings }\end{array}$ \\
\hline $\begin{array}{l}\text { Documentary } \\
\text { evidence from } \\
\text { other project- } \\
\text { specific data } \\
\text { sources }\end{array}$ & $\begin{array}{l}\text { Letters of appointment and other } \\
\text { correspondence with } \\
\text { subcontractors }\end{array}$ & $\begin{array}{l}\text { Financial data related to cost of } \\
\text { meter-readers and } \\
\text { outsourced parties } \\
\text { Operational data on meters read } \\
\text { and total number of meters }\end{array}$ & $\begin{array}{l}\text { Client proposals containing } \\
\text { suggested services to } \\
\text { prospective clients } \\
\text { Company analysis by prospective } \\
\text { client following participation } \\
\text { in a bid }\end{array}$ \\
\hline $\begin{array}{l}\text { Documentary } \\
\text { evidence } \\
\text { from general } \\
\text { firm sources }\end{array}$ & $\begin{array}{l}\text { Service record of firm's previous } \\
\text { and current projects } \\
\text { Government policy documents } \\
\text { outlining goals of black } \\
\text { empowerment and implications } \\
\text { for procurement }\end{array}$ & & $\begin{array}{c}\text { Financial and strategic analysis by } \\
\text { external consultant } \\
\text { Company website and } \\
\text { marketing materials } \\
\text { IT user manual explaining how the } \\
\text { company's IT system works }\end{array}$ \\
\hline
\end{tabular}

Interview evidence was complemented by documentary evidence. As South African municipalities procure services via tender bid processes (Bolton, 2010), tender bid documents offer significant insights into the preferences of MRS clients. In addition, other projectrelated documents and general corporate documents were available for analysis. Table 2 summarises the various items of documentary evidence, showing which pieces of documentary evidence were important in exploring which research questions. The table also distinguishes between evidence used to build theories surrounding research questions 1 and 2 , and evidence used to refute rival theories that could undermine the inferred theories.

Direct observation served as a reliability test for interview and documentary evidence, but when direct observation did provide specific operational evidence, its interpretation was 
discussed with MRS.

Given this background, the following section proceeds to develop the three research themes highlighted earlier. First, is there a link between BEE policy and the boundary decisions by firms? Second, if so, how do firms accommodate variety in BEE requirements for various clients in their boundary decisions? Third, how do firms use BEE-induced changes in their boundary structures to maintain competitive advantage?

\section{5}

\section{Analysis}

To develop the three research themes, the first subsection provides an overview of the evolution of firm boundaries at MRS. Subsequent subsections then investigate the links between these boundary changes and BEE policy.

\subsection{Overview of MRS boundaries}

The meter-reading process can be divided into three consecutive steps: (1) planning of monthly meter-reading projects according to dates set by clients; (2) collection of meter-readings; and (3) processing of meter-readings by uploading the data onto a central database, identifying discrepancies (and re-reading if required), and transmitting processed data to clients. Each of these steps involves a set of highly interdependent activities with a distinct knowledge base: planning requires the ability to manage human resources and adjust work schedules, collection requires geographic knowledge of the areas in which meter-readings are collected, as well as various skills, and processing requires computer skills and a familiarity with meter-reading processing procedures. The meter-reading value chain can therefore be described as modular (Grant, 2006), as shown in Figure 1:

Figure 1

Modular Structure of MRS Value Chain

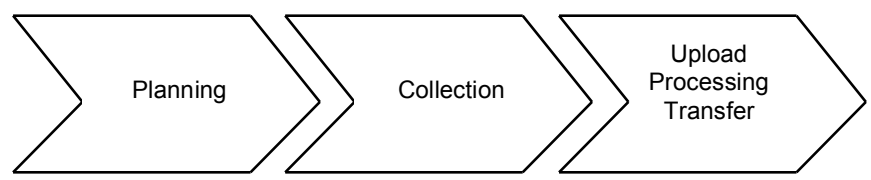

This modular structure has enabled MRS to occupy a variety of positions along the value chain, that is, to choose a variety of boundaries along the value chain. To investigate this variety, the paper studies five clients with whom MRS has been involved from 1997 to 2007. These five clients represent 90 per cent of MRS revenue over this period. Table 3 presents a summary of information for the five clients.
Information from invoices, supplemented by discussions with the owner, shed light on the vertical structure of MRS over this period. The data shows that MRS offered a verticallyintegrated service to client 1. According to discussions with the owner, MRS offered such an integrated service from its establishment in 1989. However, for clients 2 to 5, all acquired after 1999, MRS has also rendered services limited to specific modules.

Table 3

Financial information showing modules in which MRS is active

\begin{tabular}{|c|c|c|c|}
\hline Project & Party invoiced & Description of service on invoice & Modules in which MRS involved \\
\hline Project 1 & MRS bills end customer & "Full meter-reading service" & Planning, collection, processing \\
\hline Project 2 & Subcontractor bills MRS & "Reading of water meters" & Planning, processing \\
\hline Project 3 & MRS bills joint venture partner & "Administration of meter-reading \\
services" & Processing \\
\hline Project 4 & MRS bills joint venture partner & "Administration of meter-reading & Processing \\
\hline Project 5 & MRS bills end customer & $\begin{array}{c}\text { "Meter-reading services rendered, } \\
\text { including processing" }\end{array}$ & Planning, collection, processing \\
\hline
\end{tabular}


Figure 2 summarizes the boundary configurations along the metering value chain suggested by the invoice data. Highlighted cells indicate activity by MRS, while blank cells indicate outsourced activity.

Figure 2

Boundary configurations of MRS along metering value chain

\begin{tabular}{|c|c|c|c|}
\hline \multirow{2}{*}{ Boundary design } & \multicolumn{3}{|c|}{ Metering value chain } \\
\cline { 2 - 4 } & Planning & Collection & Processing \\
\hline Configuration 1 & & & \\
\hline Configuration 2 & & & \\
\hline Configuration 3 & & & \\
\hline
\end{tabular}

Even though three types of boundary configuretions are identified in Figure 2, these are not pre-defined. As will be shown in the empirical analysis, MRS created new configurations depending on the requirements of particular clients. Furthermore, it is important to note that the above-mentioned configurations do not follow one another in chronological order, but that several boundary configurations were operative simultaneously, as shown in Figure 3.

Figure 3

Chronologies of projects with different boundary configurations

\begin{tabular}{|c|c|c|c|c|c|c|c|c|c|c|c|}
\hline \multirow{2}{*}{ Project } & \multicolumn{11}{|c|}{ Time } \\
\hline & 1997 & 1998 & 1999 & 2000 & 2001 & 2002 & 2003 & 2004 & 2005 & 2006 & 2007 \\
\hline \multicolumn{12}{|l|}{ Project 1} \\
\hline \multicolumn{12}{|l|}{ Project 2} \\
\hline \multicolumn{12}{|l|}{ Project 3} \\
\hline \multicolumn{12}{|l|}{ Project 4} \\
\hline Project 5 & & & & & & & & & & & \\
\hline
\end{tabular}

Figure 3 shows that meter-reading projects have lifetimes varying from one to ten years and illustrates the overlap in project lifetimes. This confirms that MRS employs flexible boundaries to meet heterogeneous requirements, rather than periodically adjusting its overall boundaries. The empirical analyses following later in the article provide additional concurrence that the boundaries are set in accordance with the requirements of particular projects.

MRS has evolved from being a verticallyintegrated service provider in the mid-nineties to a solution provider offering client-specific services constructed by using flexible boundaries along the value chain. The aim of this paper is to study the link between these boundary changes and BEE policy. To this end, the following subsections consider the three research questions highlighted earlier.

\subsection{Research question 1 and 2: linking firm boundaries and demand-side preferences}

A study of the link between demand-side preferences and boundary changes requires explicit evidence on demand-side preferences, which may be difficult to measure for most firms. However, the municipal clients of MRS all specify their value-chain requirements and preferences in tender bid documents. Table 4 summarises these preferences for the five major clients of MRS, who together account for approximately 90 per cent of revenue over the study period. Value-chain preferences are measured in two ways: first, by means of the bid evidence mentioned above, and, second, in semi-structured interviews. The evidence from the two sources is summarised in the third column, which is headed "value-chain preference". The column distinguishes between clients with no strong value-chain preferences and those with particular preferences. For clients in the latter group, a short description of the specific value-chain requirements is provided.

Table 4 shows that the five clients have heterogeneous value-chain preferences. One client prefers meter-reading firms to use locally-procured labour from the areas in which the firms are collecting meter-readings. Two other clients expect more intensive 
collaboration efforts between meter-reading firms and favoured local suppliers, with the aim of improving the business skills of local suppliers. The remaining two clients have no strong preferences and are willing to accept the structure proposed by the bidding firm.

This paper is concerned with understanding whether this heterogeneous demand environment influences the boundary decisions of MRS. In particular, Research Question 1 focuses on whether BEE-based value chain views influence MRS boundary choice. If so, Research Question 2 focuses on whether heterogeneity in value-chain preferences (as shown in Table 4) is correlated with heterogeneity in MRS boundary decisions described earlier.

Table 4

Views of MRS clients on the value chain

\begin{tabular}{|c|c|c|c|}
\hline Client & Discussions with management & Documentary evidence & Inferred client preference \\
\hline Client 1 & BEE not considered important. & $\begin{array}{c}\text { BEE requirements not articulated in tender } \\
\text { documents, with vague reference to } \\
\text { community-based meter-readers (and lacking } \\
\text { criteria for assessment or incentives } \\
\text { to comply). }\end{array}$ & No preference. \\
\hline Client 2 & $\begin{array}{c}\text { BEE not initially important. However, } \\
\text { pressure for more direct community } \\
\text { involvement in meter-reading } \\
\text { increased over time. }\end{array}$ & $\begin{array}{c}\text { No formal tender document, but written } \\
\text { correspondence with community and } \\
\text { municipal client concerning the use of local } \\
\text { meter-readers. }\end{array}$ & $\begin{array}{c}\text { Preference. Disintegrated } \\
\text { view, with focus on } \\
\text { community procurement. }\end{array}$ \\
\hline Client 3 & $\begin{array}{c}\text { BEE essential. Client allocated work } \\
\text { to MRS on condition that it involved } \\
\text { a black partner familiar with the } \\
\text { communities in which the work is to } \\
\text { be performed. }\end{array}$ & $\begin{array}{c}\text { BEE requirements inferred from written } \\
\text { correspondence articulating need for } \\
\text { interaction with local community forum and } \\
\text { development of local enterprise. }\end{array}$ & $\begin{array}{c}\text { Preference. Disintegrated } \\
\text { view, with focus on } \\
\text { community procurement } \\
\text { and promotion of local } \\
\text { business }\end{array}$ \\
\hline Client 4 & $\begin{array}{c}\text { BEE essential. MRS contacted by } \\
\text { black partner to cooperate in a } \\
\text { tender bid. }\end{array}$ & $\begin{array}{c}\text { BEE requirements in tender documents } \\
\text { based on specific procurement policy of local } \\
\text { government, but emphasizing all of the } \\
\text { factors mentioned in the national scorecard. }\end{array}$ & $\begin{array}{c}\text { Preference. Disintegrated } \\
\text { view, with focus on } \\
\text { community procurement } \\
\text { and promotion of local } \\
\text { business }\end{array}$ \\
\hline Client 5 & $\begin{array}{c}\text { BEE not considered important. } \\
\text { Although information collected on } \\
\text { this, no particular action required. }\end{array}$ & $\begin{array}{c}\text { No formal tender document, but no reference } \\
\text { to BEE requirements in written } \\
\text { correspondence between MRS and client. }\end{array}$ & \begin{tabular}{c} 
No preference. \\
\hline
\end{tabular} \\
\hline
\end{tabular}

Table 5 studies the role of client preferences in the boundary decisions by MRS. The table relies on two sources of evidence to assess how boundary decisions respond to clients: documentary evidence and discussions with management. The findings are summarized in the final column by first classifying boundary responses at MRS into "none" and "adjust boundaries" and then stating the modules to which MRS chooses to restrict its boundaries.

Table 5 shows that boundary decisions at MRS correlate highly with the value-chain preferences of its clients: Client 2 values community procurement and MRS responds to this preference by outsourcing the collection module. The value-chain preferences of Clients 3 and 4 extend beyond community procurement and include both procurement and promotion of local business. MRS responds by restricting its boundaries to the processing module and outsourcing the collection and planning module.
Clients 1 and 5 do not exhibit strong valuechain preferences and MRS chooses to perform all activities in-house. Heterogeneity in valuechain preferences is therefore reflected in heterogeneity in firm boundaries. Figure 4 highlights the modules in which MRS is active for each client.

To guarantee the internal validity of the claim that it was demand-side pressures that led MRS to adopt flexible boundaries, it is necessary to eliminate potential supply-side explanations. One competing explanation could be that technological change has caused MRS boundary change. Hand-held devices used to electronically capture readings in the field are slowly replacing traditional paper-based meter-reading in South Africa. However, while the hand-held technology does generate minor reallocation of tasks among modules, the technology does not alter the modular structure of the value chain or favour vertical disintegration. ${ }^{2}$ Apart from 
technology, the literature suggests a range of conventional supply-side explanations for flexible boundaries, including transaction cost economics and neoclassical economic theories (Parmigiani, 2007). However, dimensions of asset specificity or production uncertainty have not changed fundamentally since the late nineties, precluding these as serious alternative explanations for the MRS boundary decision (Williamson, 1975; Whinston, 2003).

Table 5

MRS response to client views of its value chain

\begin{tabular}{|c|c|c|c|}
\hline Client & Discussions with management & Documentary evidence & $\begin{array}{l}\text { Inferred boundary } \\
\text { response }\end{array}$ \\
\hline Client 1 & $\begin{array}{l}\text { BEE not considered when bidding: "The proposal } \\
\text { was quite short, with just an outline of the service } \\
\text { to be rendered" }\end{array}$ & No reference to BEE in tender bid. & $\begin{array}{c}\text { None } \\
\text { (MRS delivers } \\
\text { integrated service). }\end{array}$ \\
\hline Client 2 & $\begin{array}{c}\text { In response to community requests, MRS } \\
\text { appointed part-time meter-readers as well as a } \\
\text { coordinator from this area to collect meter } \\
\text { readings. }\end{array}$ & $\begin{array}{l}\text { Written proposal to client and } \\
\text { correspondence with community } \\
\text { coordinator focus on training local } \\
\text { meter-readers. }\end{array}$ & $\begin{array}{l}\text { Adjust boundaries } \\
\text { (MRS focus on } \\
\text { planning and } \\
\text { processing) }\end{array}$ \\
\hline Client 3 & $\begin{array}{l}\text { MRS was contacted by a member of the } \\
\text { communities within which meter-reading was to } \\
\text { take place and agreed to form a joint venture, in } \\
\text { which the community member would be } \\
\text { responsible for planning and the collection of } \\
\text { readings and MRS for processing the data. }\end{array}$ & $\begin{array}{l}\text { Written proposal to client emphasized } \\
\text { role of MRS in processing task and } \\
\text { role of local black partner in managing } \\
\text { and executing meter-reading (planning } \\
\text { and collection). }\end{array}$ & $\begin{array}{l}\text { Adjust boundaries } \\
\text { (MRS focus on } \\
\text { processing) }\end{array}$ \\
\hline Client 4 & $\begin{array}{l}\text { Similar to Client } 3 \text {, MRS was contacted by a } \\
\text { community member, who did not have the requisite } \\
\text { experience. MRS decided to form a joint venture, in } \\
\text { which MRS is responsible for processing and the } \\
\text { community member for the planning and collection } \\
\text { of readings. }\end{array}$ & $\begin{array}{l}\text { Tender bid details a joint venture with } \\
\text { the community member, subdivision of } \\
\text { tasks show MRS involved in } \\
\text { processing and community member in } \\
\text { planning and collection. }\end{array}$ & $\begin{array}{l}\text { Adjust boundaries } \\
\text { (MRS focus on } \\
\text { processing) }\end{array}$ \\
\hline Client 5 & BEE not considered when bidding. & $\begin{array}{c}\text { No reference to BEE in proposals to } \\
\text { client. }\end{array}$ & $\begin{array}{c}\text { None } \\
\text { (MRS delivers } \\
\text { integrated service). }\end{array}$ \\
\hline
\end{tabular}

Figure 4

Boundary decisions of MRS by client

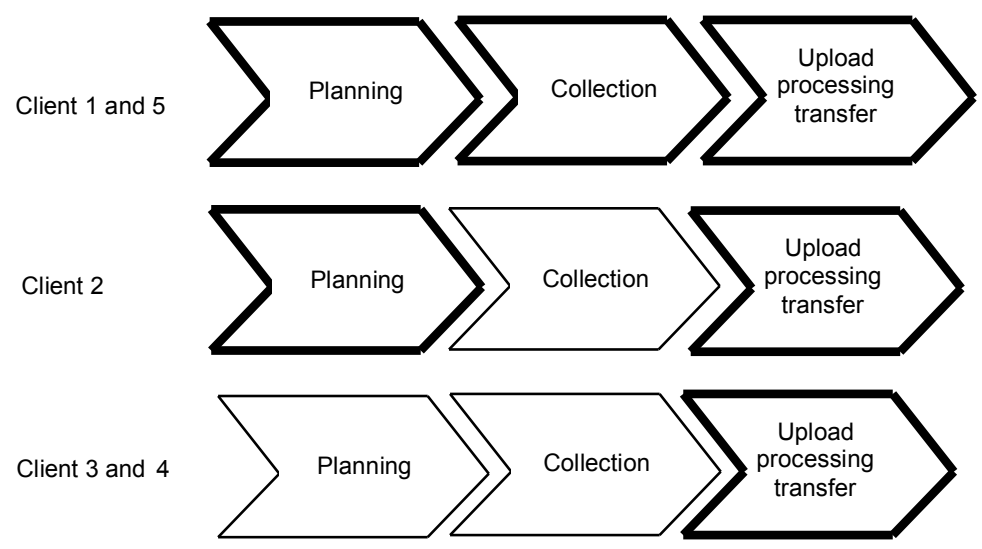

\subsection{Research question 3: strategic} benefits of flexible boundaries

Flexible boundaries may not appear to be a long-run strategic solution for MRS, given that clients increasingly prefer the involvement of more firms along the meter-reading value chain.
If the majority of clients prefer verticallyspecialized players, why not permanently change the boundaries of the firm to adopt a fully specialized position in the value chain? This question is the rationale underlying Research Question 3, which focuses on how 
the firm may implement flexible boundaries in a way that balances the BEE demands of its clients and its competitive advantage.

At first glance, it appears that MRS implements flexible boundaries to serve those few remaining clients who still prefer a single vertically-integrated firm. However, the strategic benefits of flexible boundaries extend well beyond the ability to meet heterogeneous client preferences. In particular, the case suggests that flexible boundaries confer so-called architectural knowledge, i.e. knowledge of how the modules along the value chain interrelate and co-function to produce the final product (see Jacobides, 2006).

To understand the salience of architectural knowledge in meter-reading, consider clients 2, 3 and 4, for which MRS restricts its boundaries to the processing module only. This specialized focus enables MRS to meet the value-chain preferences of these clients, as it outsources the collection and planning modules to community-based firms. The problem with outsourcing to community-based firms is that they do not hold operational knowledge beyond their own activities and hold little knowledge of how modules co-function to produce the final product - an accurate meter reading delivered to the client on time. In contrast, MRS holds architectural knowledge of all modules and their interrelationships because of the vertically-integrated service it provides to Clients 1 and 5. A verticallyintegrated solution requires MRS to have knowledge of all modules and their interrelationships. If MRS chose to restrict its boundaries and not provide a verticallyintegrated solution to clients 1 and 5 , it would not be able to manage the value chain for clients 2, 3 and 4: MRS would gradually lose the capability to understand and manage the interrelationships across the value chain.

MRS uses its architectural knowledge to undertake a managerial role to ensure the accuracy and timeliness of meter-readings. Electronic and printed marketing documents, with ubiquitous references to "management", "administration" and "experience" as well as similar references (to "operations management", among others) in tender bid documents provide evidence on this management role. MRS "management" involves more than the coordination of daily activity in a given meter-reading value chain, important as that may be. It also entails the establishment of the underlying language and organizing concepts used across the meter-reading value chain. At MRS, this language is articulated in the firm's unique proprietary computer software system. The software system assists MRS in establishing a standard language by specifying a vocabulary of organizing concepts ("meter books", "walk sequences") as well as a system of standard codes to be used by, for example, meterreaders when recording problems encountered during meter-reading (e.g. code " 11 " refers to inaccessible meters, code " 12 " to defective meters, etc.). Figure 5 illustrates the managerial role of MRS in these different modules and their interfaces:

Figure 5 shows that, even when it is responsible for only the processing module in the value chain, it still manages the planning and collection modules as well as the interfacing between collection and planning.

During interviews concerning their management role in the value chain, MRS management noted that "the client wants you to involve these guys but they also want readings delivered on time without a lot of problems". Adopting such a management role provides MRS with a competitive advantage relative to the specialized community-based firms, as acknowledged by MRS: "Our IT [the MRS meter-reading software system] and our experience of getting the job done is what sets us apart. You know, meter-reading is not just about reading, it's about planning and sticking to dates. A lot of guys [other meter-reading firms] just don't know how to do this and that's why they fail". MRS therefore adopts flexible boundaries rather than a fully specialized vertical position in order to deal with heterogeneity in the preferences of its clients. Further, flexible boundaries enable MRS to continue managing the entire value chain. In sum, the adoption of flexible boundaries at MRS was not merely a response in order to survive, but was also a strategy to ensure growth while going forward. 
Figure 5

MRS Involvement across the meter-reading value chain

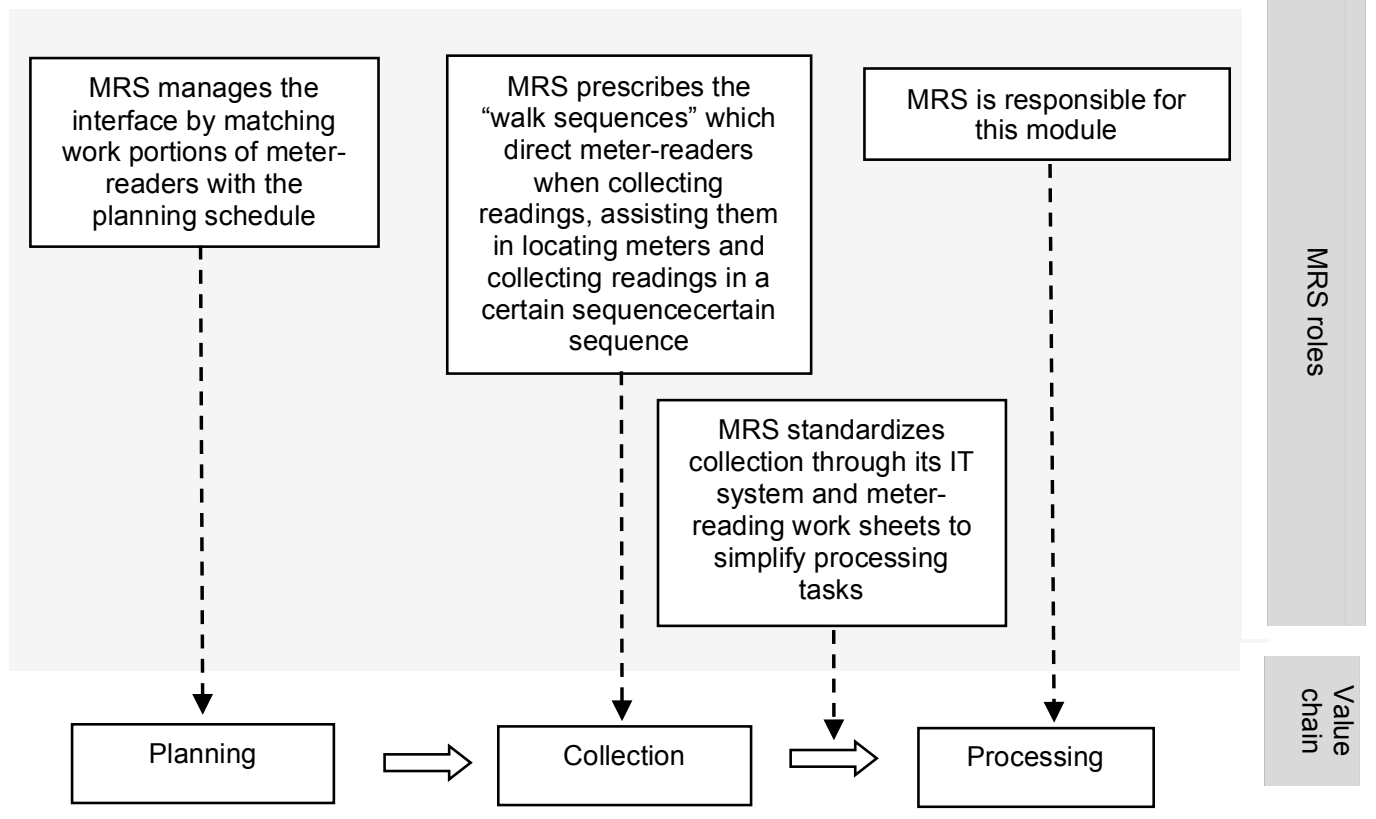

6

\section{Results}

As argued in the section on methodology, the case study method is aimed at developing theory in an inductive fashion. This requires distilling three general theoretical propositions from the specific empirical case. The analysis of the MRS case in the preceding section assists in developing three theoretical propositions, corresponding to the three research questions developed earlier. The following paragraphs outline each of these theoretical propositions and, in each case, situate the emerging theoretical proposition within the wider literature, consistent with the case study approach by Eisenhardt (1989).

\subsection{Research question 1: BEE policy and boundary choice}

The first research question centres on whether BEE policy leads to changes in the boundary decisions by firms. The case confirms that BEE policy is a demand-based intervention, i.e. that BEE policy aims to alter demand along value chains in a cascading fashion. In particular, the case study provides systematic evidence for the following theoretical proposition:
Proposition 1: Changes in demand-side preferences shaped by BEE considerations lead to concomitant changes in boundary structure to match these preferences.

The demand-side interpretation of BEE policy is consistent with a view of BEE as a form of corporate social responsibility (CSR), albeit involuntary (Arya \& Bassi, 2009; Arya \& Zhang, 2009). CSR is recognized as demand-side driven: for example, in the international food and textile value chains, firms have developed outsourcing practices and governance mechanisms to accommodate smaller players, mostly because of demandside pressure from activists and sociallyconscious buyers (Gereffi, Humphrey \& Sturgeon, 2005).

\subsection{Research question 2: Heterogeneity in BEE policy and heterogeneity in boundary choice}

The second research question centres on whether a firm faced by heterogeneous client preferences regarding BEE will adopt heterogeneous boundary structures. The case shows that $\mathrm{BEE}$ is a market-based policy that may be implemented in a variety of corporate forms 
depending on market context. BEE policy documents emphasize that the BEE balanced scorecard discussed earlier enables agents to tailor their BEE strategy to their individual environments. Andrews (2008:87-88) explores the possibility of multiple corporate responses to BEE policy and suggests that "BEE will catalyze structural change more effectively when there is decision space for organizations and sectors to ... self-discover the appropriate change for their setting". The paper supports the view that different industries may exhibit different BEE patterns: the MRS case is set in the meter-reading industry, where clients strongly emphasize BEE's value-chain aspects rather than the affirmative action employment or ownership aspects. In fact, the paper goes further by showing that, within a given sector, heterogeneity in BEE approaches by individual clients manifest in substantial heterogeneity in demand-side preferences. This suggests the following theoretical proposition:

Proposition 2: Heterogeneity in the BEE-based value-chain preferences of its clients leads the firm to choose heterogeneous boundaries.

It is particularly significant that the paper studies the impact of this heterogeneity on small firms with only a few large clients, given that much of research focuses on the corporate structure of large firms (Chabane et al., 2006). The case suggests that when South African firms face heterogeneous client preferences because of heterogeneous BEE requirements they may adopt flexible structures. The use of flexible structures to deal with BEE is consistent with the recent literature on the strategic use of flexibility under conditions of uncertainty (van Wyk, Dahmer \& Custy, 2004; Kogut \& Kulatilaka, 2006) and, specifically, with the strategic value-chain literature (Nadkarni \& Narayanan, 2007).

\subsection{Research question 3: Using BEE- induced boundary changes to retain competitive advantage}

The third research question asks how a firm implements boundary structures to both meet BEE requirements and maintain competitive advantage. The case shows that firms do not passively respond to BEE policy but explore strategic responses that balance $\mathrm{BEE}$ requirements with other organizational goals. MRS did not merely respond to the demand-side pressures, but also implemented a particular boundary choice that carried architectural benefits. In particular, MRS employed flexibility in its boundaries that enabled the firm to accommodate joint ventures and the involvement of other firms while maintaining architectural knowledge allowing MRS to manage the overall value chain processes (Santos \& Eisenhardt, 2005; Jacobides \& Billinger, 2006). The case therefore provides support for the following theoretical proposition:

Proposition 3: Flexible boundaries allow the firm to accommodate BEE preferences of clients while retaining architectural knowledge, which can be used to manage the overall value chain. Flexible boundaries therefore offer a competitive advantage to the firm.

A strategy of this type is consistent with the literature's view of flexible boundaries as both a cooperative and a competitive device: architectural management ensures cooperation across the value chain to improve efficiency, while it is also a distinctive capability distinguishing the firm from competitors.

\section{7}

\section{Conclusions}

The paper seeks to initiate a research programme on the strategic implications and, more specifically, the value chain and boundary implications of BEE policy in South Africa. The MRS case study is therefore a first attempt at analysing the mechanisms by means of which BEE policy is linked to strategic outcomes. The case study develops three theoretical propositions regarding BEE policy as a strategic variable. First, BEE policy can act as a demand-side driver of boundary change. Second, heterogeneity in BEE client preference leads to heterogeneity in a firm's boundary structures. Third, a firm implements BEE-driven boundary change in such a way that its competitive advantage is preserved.

The paper relies on a single-case study, given the 'revelatory' nature of the case. The aim is therefore analytical rather than statistical generalization. However, the next step is to investigate the extent to which this emergent 
theory generalises to a larger population of firms. Future research should therefore be extended to a variety of industries.

Also, the case study and emergent theories suggest a number of areas that require further investigation. First, it is necessary to study under which conditions ownership and employment issues, rather than value-chain issues, dominate the BEE requirements of clients. Second, it is crucially important to study the conditions under which firms respond to BEE requirements: Do firms (both local and international) avoid industries with particular BEE emphases and what is the role of competitive pressure? Third, it is necessary to understand how smaller firms differ from larger firms in their responses to BEE policy. Finally, and perhaps most important for practitioners, it is important to study how firms develop value-chain structures that both enhance their own competitive advantage and ensure sustainable long-run BEE partners in their value chains. It is not helpful to argue that firms should "co-operate" on the basis of "the greater good". Organizations, especially profitseeking firms, have specific long-run goals and act strategically in their response to government policy. Understanding the strategic nature of corporate responses to BEE is crucial and this paper is an important step towards better understanding of this.

\section{Endnotes}

1 Name changed for confidentiality reasons

2 Hand-held technology results in a re-allocation of tasks between the collection and processing modules, by allowing the upload of data and an important part of the processing activity to take place during the collection, rather than the processing, phase.

\section{Acknowledgement}

This paper is a summary of earlier research conducted under the supervision of Professor Mari Sako of the Saïd Business School, Oxford University. I wish to thank Professor Servaas van den Berg and seminar participants at Stellenbosch University as well as the anonymous referees for their comments.

\section{References}

ANDREWS, M. 2008. Is black economic empowerment a South African growth catalyst? (or could it be...). Center for International Development at Harvard University Working Paper No. 170. Available at: http://web.hks.harvard.edu/publications/getFile. aspx?Id=426 (accessed 2010-03-21).

ARYA, B. \& BASSI, B. 2009. Corporate social responsibility and broad-based black economic empowerment legislation in South Africa. Business \& Society, doi: 10.1177/0007650309332261.

ARYA, B., BASSI, B. \& PHIYEGA, R. 2008. Transformation charters in contemporary South Africa: the case of the ABSA group limited. Business \& Society Review, 113(2):227-251.

ARYA, B. \& ZHANG, G. 2009. Institutional reforms and investor reactions to CSR announcements: evidence from an emerging economy. Journal of Management Studies, 46(7):1089-1112.

BLACK, P.A. 2002. On the case for 'black economic empowerment' in South Africa. South African Journal of Economics, 70(8):1148-1162.

BOLTON, P. 2008. The public procurement system in South Africa: main characteristics. Public Contract Law Journal, 37(4):719-740.

BOLTON, P. 2010. Municipal tender awards and internal appeals by unsuccessful bidders. Potchefstroom Electronic Law Journal, 13(3):56-82.

BUCHANAN, D.A. 1999. The logic of political action: an experiment with the epistemology of the particular. British Journal of Management, 10:S73-S88.

CHABANE, N., GOLDSTEIN, A. \& ROBERTS, S. 2006. The changing face and strategies of big business in South Africa: more than a decade of democracy. Industrial and Corporate Change, 15(3):549-577.

CLARK, A. 2000. Demand-side management investment in South Africa: barriers and possible solutions for new power sector contexts. Energy for Sustainable Development, 4(4):27-35.

DEPARTMENT OF TRADE AND INDUSTRY 2007. BEE codes of good conduct. Pretoria. 
EDMONDSON, A.C. \& MCMANUS, S.E. 2007. Methodological fit in management field research. Academy of Management Review, 32(4):1155-1179.

EISENHARDt, K.M. 1989. Building theories from case study research. The Academy of Management Review, 14:532-550.

EISENHARDT, K.M. \& GRAEBNER, M.E. 2007. Theory building from cases: opportunities and challenges. Academy of Management Journal, 50:25-32.

FAUCONNIER, A. \& MATHUR-HELM, B. 2008. Black economic empowerment in the South African mining industry: a case study of Exxaro Ltd. South African Journal of Business Management, 39(4):1-14. FLYVBJERG, B. 2006. Five misunderstandings about case-study research. Qualitative Inquiry, 12(2): 219-245.

GEREFFI, G., HUMPHREY, J. \& STURGEON, T. 2005. The governance of global value chains. Review of International Political Economy, 12(1):78-104.

GRANT, R.M. 2006. The knowledge-based view of the firm, in D.O. Faulkner and A. Campbell (eds.). The Oxford Handbook of strategy. Oxford: Oxford University Press.

HALL, P.A. \& SOSKICE, D.W. 2001. Varieties of capitalism: the institutional foundations of comparative advantage. New York: Oxford University Press.

HAYES, K.T.A. 2006. Grounding African corporate responsibility: moving the environment up the agenda, in W. Visser, M. McIntosh \& C. Middleton (eds.) Corporate citizenship in Africa. Sheffield, UK: Greenleaf: 93-104.

HELFAT, C.E. \& EISENHARDT, K.M. 2004. Inter-temporal economies of scope, organizational modularity, and the dynamics of diversification. Strategic Management Journal, 25:1217-1232.

HORN, G.S. 2007. Black economic empowerment (BEE) in the Eastern Cape automotive industry: challenges and policies. South African Journal of Economic and Management Sciences, 10(4):490-503.

JACKSON, W.E., ALESSANDRI, T.M. \& BLACK, S.S. 2005. The price of corporate social responsibility: the case of black economic empowerment transactions in South Africa: Federal Reserve Bank of Atlanta.

JACOBIDES, M.G. 2005. Industry change through vertical disintegration: how and why markets emerged in mortgage banking. Academy of Management Journal, 48:465-498.

JACOBIDES, M.G. 2006. The architecture and design of organizational capabilities. Industrial and Corporate Change, 15:151-171.

JACOBIDES, M.G. \& BILLINGER, S. 2006. Designing the boundaries of the firm: from "make, buy, or ally" to the dynamic benefits of vertical architecture. Organization Science, 17:249-261.

KOGUT, B. \& KULATILAKA, N. 2006. Strategy, heuristics, and real options, in D.O. Faulkner \& A. Campbell (eds.) The Oxford handbook of strategy. Oxford: Oxford University Press.

KUHN, T.S. 1970. Logic of discovery of psychology of research? in M. Curd \& J. A. Cover (eds.) Philosophy of science: the central issues. London: W.W. Norton \& Company.

MARTIN, L. \& ROOT, D. 2010. Emerging contractors in South Africa: interactions and learning. Journal of Engineering, Design and Technology, 8(1):64-79.

MITCHELL, J.C. 1983. Case and situational analysis. Sociological Review, 31(2):187-211.

NADKARNI, S. \& NARAYANAN, V.K. 2007. Strategic schemas, strategic flexibility, and firm performance: the moderating role of industry clockspeed. Strategic Management Journal, 28:243-270.

PARMIGIANI, A. 2007. Why do firms both make and buy? An investigation of concurrent sourcing. Strategic Management Journal, 28:285-311.

POPPER, K.R. 1963. Conjectures and refutations. London: Routledge \& Keegan Paul Limited.

REPUBLIC OF SOUTH AFRICA 2006. South Africa's economic transformation: a strategy for broad-based black economic empowerment. Pretoria.

RUNDE, J. \& DE ROND, M. 2010. Evaluating causal explanations of specific events. Organization Studies, 31(4):431-450.

SANTOS, F.M. \& EISENHARDT, K.M. 2005. Organizational boundaries and theories of organization. Organization Science, 16:491-508.

SIGGELKOW, N. 2007. Persuasion with case studies. Academy of Management Journal, 50:20-24.

STRYDOM, B., CHRISTISON, A. \& MATIAS, J. 2009. An empirical investigation of the effect of black economic empowerment transactions on share prices: 1996 to 2006. African Journal of Accounting, Economics, Finance and Banking Research, 5(5):67-76. 
VAN WYK, J., DAHMER, W. \& CUSTY, M.C. 2004. Risk management and the business environment in South Africa. Long Range Planning, 37:259-276.

VISSER, W. 2005. Corporate citizenship in South Africa: a review of progress since democracy. Journal of Corporate Citizenship, 18:29-38.

WHINSTON, M.D. 2003. On the transaction cost determinants of vertical integration. Journal of Law, Economics and Organization, 19(1):1-23.

WILLIAMSON, O.E. 1975. Markets and hierarchies: analysis and antitrust implications. New York: Free Press.

WOLMARANS, H. \& SARTORIUS, K. 2009. Corporate social responsibility: the financial impact of black economic empowerment transactions in South Africa. South African Journal of Economic and Management Sciences, 12(2):180-193.

YIN, R.K. 2003. Case study research: design and methods. London: Sage Publications. 